\title{
Callitriche cophocarpa (water starwort) proteome under chromate stress: evidence for induction of a quinone reductase
}

\author{
Paweł Kaszycki $^{1}$ (D) Aleksandra Dubicka-Lisowska ${ }^{1} \cdot$ Joanna Augustynowicz ${ }^{2} \cdot$ Barbara Piwowarczyk $^{2}$. \\ Wojciech Wesołowski ${ }^{3}$
}

Received: 16 May 2017 / Accepted: 18 December 2017 / Published online: 13 January 2018

(C) The Author(s) 2018. This article is an open access publication

\begin{abstract}
Chromate-induced physiological stress in a water-submerged macrophyte Callitriche cophocarpa Sendtn. (water starwort) was tested at the proteomic level. The oxidative stress status of the plant treated with $1 \mathrm{mM} \mathrm{Cr}(\mathrm{VI})$ for 3 days revealed stimulation of peroxidases whereas catalase and superoxide dismutase activities were similar to the control levels. Employing two-dimensional electrophoresis, comparative proteomics enabled to detect five differentiating proteins subjected to identification with mass spectrometry followed by an NCBI database search. $\mathrm{Cr}(\mathrm{VI})$ incubation led to induction of light harvesting chlorophyll $a / b$ binding protein with a concomitant decrease of accumulation of ribulose bisphosphate carboxylase (RuBisCO). The main finding was, however, the identification of an $\mathrm{NAD}(\mathrm{P}) \mathrm{H}$-dependent dehydrogenase $\mathrm{FQR} 1$, detectable only in $\mathrm{Cr}(\mathrm{VI})$-treated plants. The FQR1 flavoenzyme is known to be responsive to oxidative stress and to act as a detoxification protein by protecting the cells against oxidative damage. It exhibits the in vitro quinone reductase activity and is capable of catalyzing two-electron transfer from $\mathrm{NAD}(\mathrm{P}) \mathrm{H}$ to several substrates, presumably including $\mathrm{Cr}(\mathrm{VI})$. The enhanced accumulation of FQR1 was chromate-specific since other stressful conditions, such as salt, temperature, and oxidative stresses, all failed to induce the protein. Zymographic analysis of chromate-treated Callitriche shoots showed a novel enzymatic protein band whose activity was attributed to the newly identified enzyme. We suggest that $\mathrm{Cr}(\mathrm{VI})$ phytoremediation with $C$. cophocarpa can be promoted by chromate reductase activity produced by the induced quinone oxidoreductase which might take part in $\mathrm{Cr}(\mathrm{VI}) \rightarrow \mathrm{Cr}(\mathrm{III})$ bioreduction process and thus enable the plant to cope with the chromate-generated oxidative stress.
\end{abstract}

Keywords Macrophyte - Aquatic plants · Hexavalent chromium - Biological reduction · Phytoremediation - Oxidative stress · Quinone dehydrogenase

\section{Responsible editor: Elena Maestri}

Electronic supplementary material The online version of this article (https://doi.org/10.1007/s11356-017-1067-y) contains supplementary material, which is available to authorized users.

Paweł Kaszycki

p.kaszycki@ogr.ur.krakow.pl

1 Unit of Biochemistry, Institute of Plant Biology and Biotechnology, Faculty of Biotechnology and Horticulture, University of Agriculture in Kraków, al. 29 Listopada 54, 31-425 Kraków, Poland

2 Unit of Botany and Plant Physiology, Institute of Plant Biology and Biotechnology, Faculty of Biotechnology and Horticulture, University of Agriculture in Kraków, al. 29 Listopada 54, 31-425 Kraków, Poland

3 Unit of Genetics, Plant Breeding and Seed Science, Institute of Plant Biology and Biotechnology, Faculty of Biotechnology and Horticulture, University of Agriculture in Kraków, al. 29 Listopada 54, 31-425 Kraków, Poland

\section{Introduction}

Anthropogenic pollution with $\mathrm{Cr}$ compounds has become a worldwide problem due to extensive use of this metal in a number of industrial applications and vehicular transport (Shadreck and Mugadza 2013; Singh et al. 2013; Zayed and Terry 2003). Chromium may appear at various oxidation states forming chemical agents of different toxicities, solubilities, and stabilities (Kotaś and Stasicka 2000; Zayed and Terry 2003), and among these, chromate (Cr(VI)) is the most hazardous to living organisms (Saha et al. 2011; Zhitkovich 2011). Chromate ion $\left(\mathrm{CrO}_{4}{ }^{2-}\right)$ structurally resembles the sulfate anion $\left(\mathrm{SO}_{4}{ }^{2-}\right)$ and therefore it becomes actively incorporated by cells mainly through non-specific sulfate transporter systems and in the lesser extent through $\mathrm{HPO}_{4}{ }^{2-}$ carriers (Cervantes et al. 2001; Prado et al. 2016; Singh et al. 2013). Then, inside cells, $\mathrm{Cr}(\mathrm{VI})$ as a strong oxidant interacts with 
cell constituents and undergoes rapid reduction due to both enzymatic and non-enzymatic reactions (Cervantes et al. 2001; Chandra and Kulshreshtha 2004; Shanker et al. 2005, 2009). Chromate bioreduction is in fact a gradual and complex route involving formation of $\mathrm{Cr}(\mathrm{V})$ and $\mathrm{Cr}(\mathrm{IV})$ intermediates responsible for generation of reactive oxygen species (ROS). In plants, many of these byproducts lead to adverse stress effects by causing severe physiological disorders and oxidative damage (Oliveira 2012; Panda and Choudhury 2005; Singh et al. 2013).

For the above reasons, $\mathrm{Cr}$ decontamination actions need to be undertaken. Among various methods implemented to date environmentally, bioremediation and especially phytoremediation appear as the most promising approaches (Parvaiz 2016). In biotechnological applications, plants capable of enhanced chromate uptake and accumulation as well as of its reduction to the less toxic forms are of particular interest since they bring possibilities for elaborating cheap, non-invasive, and efficient industrial-scale methods for soil reclamation and water cleanup (Prado et al. 2016; Yang et al. 2005; Zayed and Terry 2003). However, biological remediation of environmental contamination with chromium compounds involves complex and divergent processes (Chandra and Kulshreshtha 2004; Panda and Choudhury 2005; Shanker et al. 2005, 2009). In the case of higher plants, chromium stress negatively affects cellular metabolism at different functional levels triggering variant reactions that enable some species to adapt to this heavy metal, resist its action, or detoxify hazardous intermediates (Prado et al. 2016; Shanker et al. 2009; Zayed and Terry 2003).

Chromate detoxication and/or protective mechanisms in plants are complex, may involve multiple factors, and can become manifested at different organizational levels related to plant metabolism, physiology, development, or structure. For the above reasons, they are not yet fully explained and understood (see Prado et al. 2016 for a recent critical review). Moreover, these processes differ depending on the strategy used by particular species to cope with the metal toxicity. Based on these divergent strategies, plants can be categorized as $\mathrm{Cr}$ excluders, indicators, or accumulators (Dalvi and Bhalerao 2013). For the case of Cr-accumulating and Crtolerant plants, it is well evidenced that the chromate stress reaction involves induction of oxidative stress response systems. This is achieved by enhancing the activities of antioxidant enzymes (superoxide dismutase (SOD), catalase (CAT), peroxidase, glutathione reductase, ascorbate peroxidase, dehydroascorbate reductase, monodehydroascorbate reductase, as well as several others, Ovečka and Takáč 2014; Shanker et al. 2005; Singh et al. 2013) as well as by stimulating bioreduction of $\mathrm{Cr}(\mathrm{VI})$ to the final $\mathrm{Cr}(\mathrm{III})$ form considered more stable and less toxic (see discussion below). The described processes may, in turn, result in altered proteomic profiles whose detailed analysis is expected to broaden our knowledge on $\mathrm{Cr}$ bioconversion mechanisms and response strategies.

The mechanisms of chromate uptake, accumulation, and metabolism have been studied for terrestrial plants more thoroughly than for macrophytes (Shanker et al. 2005, 2009), although the latter group seems to be a better choice for phytoremediation purposes (Tel-Or and Forni 2011). This is because aquatic plants, especially the water-floating and submerged species, usually exhibit higher accumulation potential and have evolved distinct physiological and biochemical pathways due to their larger contact area with the surrounding water environment (Chandra and Kulshreshtha 2004). In consequence, the assimilative organs of macrophytes are affected directly by the solution and this interaction becomes particularly important in the case of heavy metal presence.

Several aquatic plants have been proposed as efficient phytoremediators of $\mathrm{Cr}$ contamination (Prado et al. 2016; Singh et al. 2013, and the references therein). Among these is the recently studied genus Callitriche that appears as a suitable candidate for environmental biotechnological use (Augustynowicz et al. 2014b; Favas et al. 2012, 2014). In particular, Callitriche cophocarpa Sendtn. (water starwort), a widespread species growing both in stagnant and running waters, was shown to reveal unusual response to chromate proving to be a potent $\mathrm{Cr}$ phytoremediator and accumulator (Augustynowicz et al. 2010, 2013a, 2013b, 2016). It exhibited enhanced capability of both $\mathrm{Cr}(\mathrm{VI})$ and $\mathrm{Cr}(\mathrm{III})$ phytoextraction from contaminated waters and extremely high capacity to bind $\mathrm{Cr}\left(3900 \mathrm{mg} \mathrm{kg}^{-1}\right.$ for 5-day treatment at $1 \mathrm{mM} \mathrm{Cr}(\mathrm{VI}))$. Furthermore, it revealed extraordinary potential in terms of chromate accumulation rate (up to $1.8 \%$ of dry mass which makes it a $\mathrm{Cr}$ hyperaccumulator), intratissular bioreduction kinetics (a postulated detoxication pathway), and bioconcentration factor (BCF determined as 74 for a 5day treatment of the shoots with $1 \mathrm{mM} \mathrm{Cr}(\mathrm{VI})$, the value close to that of commercially used sorbents). Upon incubation with $50-\mu \mathrm{M}$ chromate, $C$. cophocarpa accumulated $>0.1 \%$ of $\mathrm{Cr}$ with no noticeable changes in the plant physiological status. All the above characteristics imply that the macrophyte has evolved efficient adaptive mechanisms against chromate stress and can respond to $\mathrm{Cr}(\mathrm{VI})$ treatment atypically.

So far, little has been done with regard to the studies of chromate-induced response of macrophytes at the level of detectable proteomes. Such research is of high interest, especially for the case of submerged plants that can interact with $\mathrm{Cr}$ compounds directly via their shoots. Therefore, besides particular applicability of $C$. cophocarpa for phytoremediation of aquatic systems, this species can serve as a good model to study chromium effect on cells and tissues. The main aim of the work is to reveal whether chromate treatment alters a protein profile of water starwort as detected with two-dimensional electrophoresis. Then, based on identification of the differentiating proteins with mass-spectrometry 
and bioinformatic tools, an attempt was made to establish whether the observed changes are specific to $\mathrm{Cr}(\mathrm{VI})$ and if they can account for the abovementioned unusual C. cophocarpa phytoremediation properties.

\section{Materials and methods}

\section{Plant material}

For the study, C. cophocarpa Sendtn. was grown under in vitro conditions. The source plant material had earlier been collected from its natural habitat: the Dlubnia river located in Southern Poland (N 50 15' 58'/E $19^{\circ} 56^{\prime} 24.9^{\prime \prime}$ ) during spring of 2012 (May). Healthy, undamaged shoots were rinsed for 10 min with a running, tap water. Next, the material was surface-sterilized in $70 \%$ ethanol for $25 \mathrm{~s}$, followed by immersing in $0.5 \%$ aqueous solution of sodium hypochlorite for $2 \mathrm{~min}$, and finally, rinsing five times with the sterile distilled water. Sterilized shoot fragments with apical buds (5$10-\mathrm{mm}$ length) were placed in a liquid MS medium (Murashige and Skoog 1962) composed of macro- and microelements supplemented with vitamins and $1 \%$ sucrose. Every 6-8 weeks, the young shoots were transferred to a fresh medium. Plants were grown in a phytotron chamber (model FD 500, Biosell, Poland) under the following conditions: $16 \mathrm{~h}$ of photon flux density of $40 \mu \mathrm{mol} \mathrm{m} \mathrm{m}^{-2}$ and $8 \mathrm{~h}$ of darkness, at $22-{ }^{\circ} \mathrm{C}$ day $/ 18{ }^{\circ} \mathrm{C}$ night. Light spectrum and intensity were similar to that applied in previous studies (Augustynowicz et al. 2016) and were found sufficient for normal plant growth resembling the conditions typical of Callitriche natural environment.

\section{Plant incubation with chromate}

Two grams of C. cophocarpa shoots was typically incubated for $72 \mathrm{~h}$ in $100 \mathrm{ml}$ of MS basal salt medium supplemented with 1-mM chromate $\left(\mathrm{CrO}_{4}{ }^{2-}\right)$ applied by dissolving potassium chromate $\mathrm{K}_{2} \mathrm{CrO}_{4} 10$-mM stock solution directly into the plant medium (the chemical formula of potassium chromate, given as canonical SMILES is as follows: [O $-][\mathrm{Cr}](=\mathrm{O})(=\mathrm{O})\left[\mathrm{O}^{-}\right] \cdot[\mathrm{K}+] \cdot[\mathrm{K}+]$; for detailed information see compound summary for CID 24597 in the PubChem Open Chemistry Database, https://pubchem.ncbi.nlm.nih.gov/ compound/24597\#section=Top; accession date: November 2017). Time, temperature, and light regimes of cultivation were as described above. Such conditions were established to cause cellular stress but were not lethal and upon removing $\mathrm{Cr}(\mathrm{VI})$ from the medium the plants fully recovered (see "Results"). In control experiments, the same amount of plant material was incubated in the MS medium. Morphological observations of $C$. cophocarpa shoots were carried out with a binocular microscope Nikon SMZ 1500.

\section{Other stress conditions}

Temperature stress was introduced by 24 -h incubation in the MS medium at $33{ }^{\circ} \mathrm{C}$, then $48 \mathrm{~h}$ at control conditions. Salt stress was exerted by incubation in $150-\mathrm{mM} \mathrm{NaCl}$ for $24 \mathrm{~h}$, then in MS medium for $48 \mathrm{~h}$. Oxidative stress was applied either by 5 -min incubation with $0.1-\mathrm{mM}$ paraquat (methylviologen) or 5-min treatment with 1-mM hydrogen peroxide and then cultivation in the MS medium for $72 \mathrm{~h}$. Note that all the applied stress-inducing factors had earlier been thoroughly tested at variant concentrations and treatment times. This enabled to obtain conditions providing considerable stress but not lethal to the plant (data not shown). All the incubations were performed in a phytotron chamber under the conditions described above. It was assumed that a 72-h incubation time was necessary for Callitriche to evolve the stresslike phenotype upon the tested factors, which was based on another study of Lemna minor L. time-dependent response to stress agents (Forni et al. 2012). After incubations, the plants were washed thrice in distilled water and kept frozen at $20{ }^{\circ} \mathrm{C}$.

\section{Preparation of protein samples for gel electrophoresis}

Because of the relatively low protein concentration found for Callitriche tissues and very high amount of interfering compounds, especially phenolics and their glycosides (Augustynowicz et al. 2014a), the total plant material content for electrophoretic analyses was extracted using the method of phenol-SDS buffer extraction without sonication, elaborated by Chatterjee et al. (2012) with some necessary modifications. One gram of shoots was ground with liquid nitrogen in a mortar and extracted with $3 \mathrm{ml}$ of homogenization buffer containing 30\% sucrose, $2 \%$ SDS, $0.1-\mathrm{M}$ Tris- $\mathrm{HCl}, 5 \% \beta-$ mercaptoethanol, and 1-mM PMSF (phenyl methyl sulfonyl fluoride), $\mathrm{pH}$ 8.0. Then, $3 \mathrm{ml}$ of Tris-buffered phenol was added and the mixture vortexed for $15 \mathrm{~min}$ at $4{ }^{\circ} \mathrm{C}$, then centrifuged at $8000 \times g$ at $4{ }^{\circ} \mathrm{C}$ for $15 \mathrm{~min}$. The phenolic fraction was collected, $3 \mathrm{ml}$ of a homogenization buffer added again, and the procedure of shaking and centrifugation was repeated. The phenolic phase was collected, centrifuged, and precipitated with $0.1-\mathrm{mM}$ ammonium acetate in cold methanol at $-20^{\circ} \mathrm{C}$ overnight. Then, the mixture was centrifuged at $10,000 \times g$ for $30 \mathrm{~min}$ at $4{ }^{\circ} \mathrm{C}$ and the pellet washed three times with $0.1-\mathrm{mM}$ ammonium acetate in cold methanol and once with $80 \%$ cold acetone. The resultant precipitate was dried at room temperature and kept frozen at $-80{ }^{\circ} \mathrm{C}$.

\section{SDS-PAGE electrophoresis}

Protein pellets were solubilized and denatured with a loading buffer $(0.5-\mathrm{M}$ Tris-HCl, pH $6.8,10 \%$ SDS, $10 \% \beta$ mercaptoethanol, $20 \%$ glycerol, $0.05 \%$ bromophenol blue) 
at $100{ }^{\circ} \mathrm{C}$ for $5 \mathrm{~min}$. SDS-PAGE was performed according to Laemmli (1970) using a BioRad MiniProtean System, applying $4 \%$ stacking and $10 \%$ separating polyacrylamide gels at $20-\mathrm{mA}$ per gel. The total of $30 \mu \mathrm{g}$ protein was loaded per well. After electrophoresis, the gels were stained with a Coomasie Brillant Blue R250 (Sigma). For calibration of molecular mass a BlueEye Prestained Protein Marker (Sigma) set was used. Protein concentration in all extracts and samples was determined using a Bradford (1976) method with bovine serum albumin (BSA) as a standard.

\section{DE electrophoresis}

For protein isoelectrofocusing (IEF, the first dimension), the protein pellet was solubilized in a rehydration buffer (7-M urea, 2-M thiourea, 2\% CHAPS, $0.002 \%$ bromophenol blue, 20-mM DTT, $1 \%$ ampholyte buffer (BioLyte, BioRad)) to a final volume of $150 \mu \mathrm{l}$ and loaded onto 7-cm IPG strips (BioRad Ready Strip) of the pI range 3-10, and then, in an independent run, at $\mathrm{pI}$ range 5-8. Passive rehydration was carried out for $12 \mathrm{~h}$ at $20^{\circ} \mathrm{C}$ and the isoelectric focusing was performed at $20^{\circ} \mathrm{C}$ (Protean IEF Cell, first step $250 \mathrm{~V}$ for $20 \mathrm{~min}$, second step $4000 \mathrm{~V}$ for $120 \mathrm{~min}$, third step $4000 \mathrm{~V}$, $10,000 \mathrm{~V} \mathrm{~h}$ ). Prior to the SDS-PAGE, the IPG strips were equilibrated for $10 \mathrm{~min}$ in buffer I containing 1\% DTT, 6-M urea, 75-mM Tris-HCl, $\mathrm{pH} 8.8,30 \%$ glycerol, and 2\% SDS and then, in the second step, for $10 \mathrm{~min}$ in buffer II consisting of $2.5 \%$ iodoacetamide, 6-M urea, 75-mM Tris $\mathrm{HCl}$, $\mathrm{pH} 8.8$, $30 \%$ glycerol, and $2 \%$ SDS. The SDS-PAGE (the second dimension) was performed according to the protocol described in the section above using a BioRad Protean II xi Cell $16 \times 16$ $\mathrm{cm}$ slab unit. In order to achieve maximum reproducibility of spot patterns for proteome comparison, a pair of IPG strips, obtained upon IEF of either control or Cr-treatment experiment, were placed side-by-side onto one $16-\mathrm{cm}$ polyacrylamide gel and then overlaid with low melting-point agarose (ReadyPrep overlay agarose, BioRad). Protein separation was carried out at $20 \mathrm{~mA}$ per gel for about $6 \mathrm{~h}$. After electrophoresis, the gels were silver-stained as described by Jungblut and Seifert (1990), scanned, and digitalized (DNr Bio-Imaging Systems MiniBis Pro, Israel, equipped with a 16-bit, 1.3 Mpix CCD camera). Then, the resultant proteome maps were matched to identify differentiating spots. Spot detection and quantification were done automatically employing either the Vision Works 2D Lite (UVP) software or Melanie 7.0 (Genebio), followed by manual verification. The amount of protein in each analyzed spot was calculated as a spot pixel density (grayscale) after subtracting gel background value. Then, to compensate for variability of gel staining, protein abundance was given as a relative density upon normalization procedure based on the densities of four selected spot marks representing invariant proteins that appeared on all the tested gels. For each set of differentiating spots in replicated gels, standard deviation of the fold change was calculated.

Three Callitriche extracts obtained upon independent physiological experiments were used for proteome mapping. Then, electrophoretic protein profiling of each set of extracts (Cr(VI) treatment and control) was done twice, using IPG strips of two $\mathrm{pH}$ ranges: $3-10$ and 5-8. Spot pattern differences were examined for all the replicate gel pairs. In order to properly select only the differentially abundant proteins, we made sure that the candidate spots showed accumulation changes in all of the gel replicates.

For subsequent MS/MS analyses, spot excision was made using the 2DE gels stained without adding glutaraldehyde to the sensitizing solution in order to improve protein identification. Also, to reduce the number of overlapping proteins, the IEF step was performed at $\mathrm{pH}$ ranging from 5 to 8 .

\section{MS/MS protein identification}

Protein identification was done at the Institute of Biochemistry and Biophysics of the Polish Academy of Sciences, Warsaw, Poland. The differentiating spots were excised manually and placed in Eppendorf tubes. Then, the gel pieces were dried with acetonitrile and subjected to reduction with $10-\mathrm{mM}$ DTT in $100-\mathrm{mM} \mathrm{NH}_{4} \mathrm{HCO}_{3}$ for $30 \mathrm{~min}$ at $57^{\circ} \mathrm{C}$. Cysteine residues were alkylated with $0.5-\mathrm{M}$ iodoacetamide in $100-\mathrm{mM} \mathrm{NH}_{4} \mathrm{HCO}_{3}$ (45 min in a darkroom at room temperature) and the proteins were digested overnight with $10-\mathrm{ng} / \mu \mathrm{l}$ trypsin in $25-\mathrm{mM} \mathrm{NH}_{4} \mathrm{HCO}_{3}$ (Promega) at $37{ }^{\circ} \mathrm{C}$. The resultant peptide samples were concentrated and desalted on a RPC18 precolumn (Waters). Further peptide separation was achieved on a nanoultra performance liquid chromatography (UPLC) RP-C18 column (Waters, BEH130 C18 column, 75- $\mu \mathrm{m}$ i.d., 250-mm length) of a nanoACQUITY UPLC system, using a 45 min linear acetonitrile gradient. The column outlet was directly coupled to the electrospray ionization (ESI, voltage of $1.5 \mathrm{kV}$ ) ion source of the Orbitrap Velos type mass spectrometer (Thermo), working in the regime of data dependent MS to MS/MS switch with HCD type peptide fragmentation. A blank run to ensure that there was no cross contamination from previous samples preceded each analysis. Raw data files were preprocessed with Mascot Distiller software (version 2.5, MatrixScience). The obtained peptide masses and fragmentation spectra were matched to the National Center Biotechnology Information (NCBI) non-redundant database no. 20150115 (57,412,064 sequences; 20,591,031,683 residues), with a Viridiplantae filter using the Mascot search engine (Mascot Server v. 2.4.1, MatrixScience) and the probability-based algorithm. The following search parameters were applied: enzyme specificity set to trypsin, peptide mass tolerance to $\pm 30 \mathrm{ppm}$, and fragment mass tolerance to \pm $0.1 \mathrm{Da}$. The protein mass was left as unrestricted and mass values as monoisotopic with one missed cleavage being 
allowed. Alkylation of cysteine by carbamidomethylation was set as fixed and the oxidation of methionine as a variable modification. Multidimensional protein identification technology-type (MudPIT-type) and/or the highest number of peptide sequences were selected. Mascot peptide ion scores served as bases for ranking protein hits. Each ion score was expressed as $-10 \cdot \log (P)$, where $P$ is the probability that the observed match was a random event. Individual ions scores $\geq$ 43 indicated identity or extensive homology $(p<0.05)$. The highest scores in the NCBI database search were matched to each analyzed spot.

\section{Preparation of protein extracts for enzymatic analyses}

To obtain native protein extracts for zymographic analysis of quinone reductase $(\mathrm{QR}), 0.8 \mathrm{~g}$ of shoots was frozen in liquid nitrogen, ground in a mortar, and suspended in $1.1 \mathrm{ml}$ of homogenization buffer containing $100-\mathrm{mM}$ Tris-acetate, $\mathrm{pH}$ 8.0, 100-mM potassium acetate, $\mathrm{pH}$ 8.0, 2-mM EDTA, 5-mM DTT, 250-mM sodium ascorbate, and $10 \% v / v$ glycerol (Laskowski et al. 2002). The samples were centrifuged at $10,000 \times g, 4{ }^{\circ} \mathrm{C}$ for $15 \mathrm{~min}$, and the supernatant was collected. For activity assays of antioxidant enzymes, $0.8 \mathrm{~g}$ of frozen shoots was ground in a mortar and extracted with $2 \mathrm{ml}$ of 50-mM Tris- $\mathrm{HCl}$ buffer, $\mathrm{pH}$ 7.0, containing $1 \mathrm{mM}$ of PMSF. Protein extracts were centrifuged as above.

\section{Zymographic analysis of quinone reductase (QR)}

For zymographic QR assay, a native-PAGE electrophoresis was performed at non-denaturing conditions using $10 \%$ separating gel and a $4 \%$ stacking gel. Samples were mixed with a loading buffer containing $0.5-\mathrm{mM}$ Tris- $\mathrm{HCl}, \mathrm{pH} 6.8,20 \%$ glycerol, and $0.05 \%$ bromophenol blue and then $13 \mu \mathrm{g}$ of protein was loaded per well. Electrophoresis was carried out at $50 \mathrm{~V}$ for $20 \mathrm{~min}$ and then at $75 \mathrm{~V}$ per gel (Mini Protean System, BioRad). The enzymatic staining technique was elaborated based on a QR assay described by Prochaska and Santamaria (1988) and Sharma et al. (1996) with some modifications. The reaction mixture contained $4.5 \mathrm{ml}$ of $0.5-\mathrm{M}$ Tris, $600-\mu \mathrm{l}$ Tween-20, $60 \mathrm{mg}$ of BSA, $27 \mathrm{mg}$ of MTT (3-(4,5-dimethylthiazol-2-yl)-2,5-diphenyl tetrazolium bromide), and $90 \mu \mathrm{l}$ of 50-mM menadione substrate. The reaction was launched with $54 \mu \mathrm{l}$ of 50 -mM NADPH. The resultant gels were digitalized after $60 \mathrm{~min}$ of staining.

\section{Assays of enzymatic markers of oxidative stress}

Catalase (CAT) activity was measured with a modified spectrophotometric method of Aebi (1984) by a decrease of $\mathrm{H}_{2} \mathrm{O}_{2}$ as observed at $240 \mathrm{~nm}$ in a reaction mixture containing $1 \mathrm{ml}$ of 54-mM solution of hydrogen peroxide in 50-mM potassium phosphate buffer, $\mathrm{pH} 7.0$, and $1.8 \mathrm{ml}$ of the buffer. The reaction was initiated with the addition of $200 \mu$ of a sample and the absorbance decrease was measured at $240 \mathrm{~nm}$ after $1 \mathrm{~min}$. Superoxide dismutase (SOD) activity was determined according to the method of Beauchamp and Fridovich (1971) with some modifications. The reagent mix was prepared by mixing of $2.18 \mathrm{ml}$ of $100-\mathrm{mM}$ potassium phosphate buffer, $\mathrm{pH} 7.8$, $0.4 \mathrm{ml}$ of 1.5 -mM NBT (nitro blue tetrazolium), $0.2 \mathrm{ml}$ of 55 $\mathrm{mM}$ methionine, $0.2 \mathrm{ml}$ of $0.12-\mathrm{mM}$ riboflavin, and $20 \mu \mathrm{l}$ of a sample. The reaction solution was illuminated with a $36-\mathrm{W}$ fluorescent lamp for $15 \mathrm{~min}$. A decrease in absorbance was measured spectrophotometrically at the wavelength of $560 \mathrm{~nm}$. Peroxidases (total activity) were assayed according to Lück (1963). A 2.98-ml volume of 50-mM phosphate buffer, $\mathrm{pH} 6.2$, was mixed with $0.1 \mathrm{ml}$ of $1 \% \mathrm{p}$-phenylenediamine and $0.1 \mathrm{ml}$ of $0.1 \% \mathrm{H}_{2} \mathrm{O}_{2}$. The reaction was started with the addition of $20 \mu \mathrm{l}$ of the 10-times diluted sample. The absorbance at $485 \mathrm{~nm}$ was measured after 1 and 2 min of incubation. Specific activities of all the above enzymes were expressed as numbers of activity units per $\mathrm{mg}$ protein. All the assays were done in triplicates. Statistical evaluation was performed with the one-way ANOVA variance analysis. Statistical differences between mean values were verified with a Tukey post hoc test $(\alpha=0.05$ and $n=3$, MATHLAB 2016a statistical software module).

\section{Reagents}

All the chemicals and reagents were of analytical or electrophoretic grades. Nanopure water, IPG strips, agarose, and ampholyte solution were from BioRad. Sucrose, potassium acetate, phosphate, sodium ascorbate, sodium chloride, and hydrogen peroxide were obtained from POCh Gliwice, Poland. The MS medium was purchased from Duchefa. Methylviologen (paraquat) and NBT were from MP Biomedicals. All other chemicals and enzymes were purchased from Sigma-Aldrich.

\section{Results}

In order to study the proteomic response of $C$. cophocarpa to $\mathrm{Cr}(\mathrm{VI})$, the plants were incubated for $72 \mathrm{~h}$ with $1-\mathrm{mM}$ potassium chromate, which is at conditions evaluated experimentally to be sublethal. In independent experiments of this study, it was established that the treatment caused physiological stress and led to morphological toxicity symptoms covering chlorosis and necrosis of shoots, shortening of apical internodes, and hampered development of apical buds (Fig. 1). Importantly, these effects were reversible since after washing out the $\mathrm{Cr}(\mathrm{VI})$ solution and further cultivating in the MS medium, full recovery was achieved within several days with no manifestations of any disorders. 

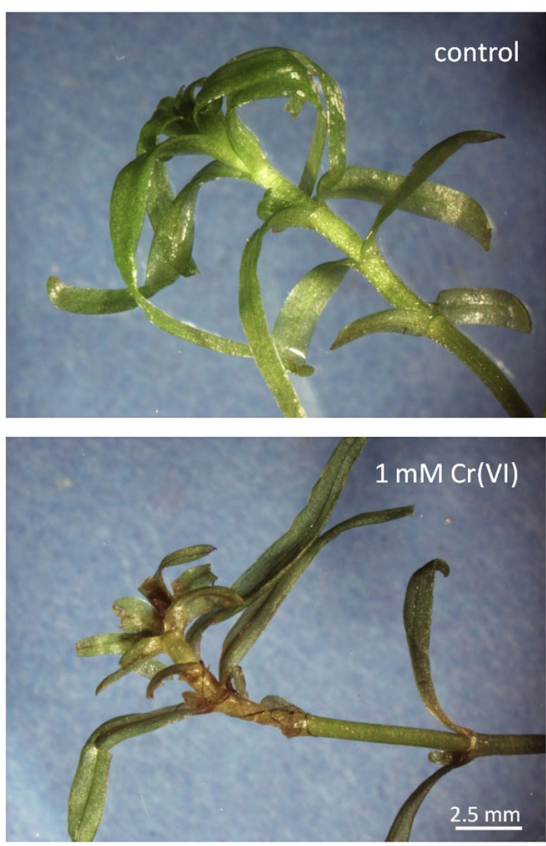

Fig. 1 Representative photographs of C. cophocarpa apex shoots of control plants and the ones treated for $72 \mathrm{~h}$ with $1-\mathrm{mM}$ chromate

Preliminary comparative protein profiling upon chromate treatment was carried out with the SDS-PAGE. The electrophoretic paths show no detectable differences in terms of protein patterns (Fig. 2). Approximately 45 bands can be detected, each revealing similar protein abundances for both control conditions and the $\mathrm{Cr}(\mathrm{VI})$-treated plants. To obtain protein maps with enhanced resolution and protein detectability, two-dimensional electrophoresis was employed with a silver-staining technique. The resultant protein profiles, as exemplified in Fig. 3a for IPG strips ranging from $\mathrm{pH} 3$ to 10 , reveal five repetitive spot differences indicating proteins with altered accumulation. The spots have been numbered consecutively and they represent the proteins induced de novo (1,2, marked by green circles) as well as the ones down-regulated $(3,4,5$, red circles) upon chromate treatment. The most pronounced difference can be observed for the spot no.1 which was strongly induced only by $\mathrm{Cr}(\mathrm{VI})$ presence and was never detected in the control experiment. That is why we decided to show the surrounding region (marked by a square in Fig. 3a) in a more detail that is using the IPG strip with the zoomed $\mathrm{pH}$ range of 5-8. The region of interest is presented in Fig. 3b. The applied narrower pI range allowed much higher resolution, prevented spot overlapping, and enabled to excise distinct spots, now well separated from the neighboring proteins. The spots of Fig. 3, qualified as the ones representing differentiating proteins, were excised from gels and subjected to MS/MS sequencing followed by bioinformatics-based identification. The results are given in Table 1.

The most important observation is high-ranked identification of the induced protein with a $M_{\mathrm{W}}=21.5 \mathrm{kDa}$ and $\mathrm{pI}=6.3$ (the observed values, spot no. 1), found to be closely related to the FQR1 dehydrogenase from Vitis vinifera $\mathrm{L}$.. This enzyme

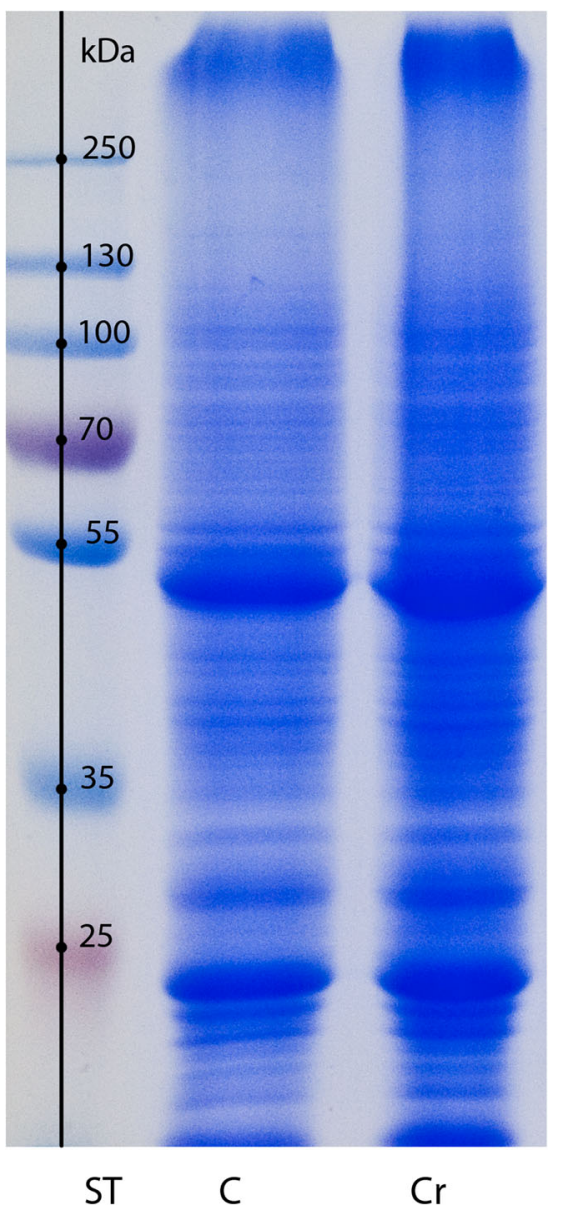

Fig. 2 SDS-PAGE protein profiles of shoot extracts of Callitriche cophocarpa treated with 1-mM chromate for $72 \mathrm{~h}(\mathrm{Cr})$. C, control (untreated plant); ST, protein standard markers

is a flavin mononucleotide-binding, $\mathrm{NAD}(\mathrm{P}) \mathrm{H}$-dependent quinone dehydrogenase that exhibits the in vitro and presumably also in vivo activity of a quinone reductase (Laskowski et al. 2002). Among the other well-scored matches was the spot no. 2 with $M_{\mathrm{W}}=24.2 \mathrm{kDa}$ and $\mathrm{pI}=7.3$, identified as the light harvesting chlorophyll $a / b$ binding protein (LHCB) from Hedera helix $\mathrm{L}$. This was the second only protein found to be induced upon chromate stress. Spots no. 3 (the observed values of $\left.M_{\mathrm{W}}=58.0 \mathrm{kDa}, \mathrm{pI}=6.7\right)$ and $4\left(M_{\mathrm{W}}=44.8 \mathrm{kDa}\right.$, $\mathrm{pI}=7.6$ ) represent down-regulated proteins identified as large RuBisCO subunits from Callitriche hamulata Kütz. and Antirrhinum majus L., respectively.

Note that for the case of spot no. 4, the initial, randomly made peptide scoring yielded unreliable match of a "hypothetical protein PRUPE ppa008516mg from Prunus persica (L.) Batsch." However, both the protein taxonomic status (Prunus genus distant from Callitriche) and discrepancies between the theoretical PRUPE molecular mass and $\mathrm{pI}$ values $\left(M_{\mathrm{W}}=36 \mathrm{kDa}\right.$ and $\mathrm{pI}=$ 9.25 ) vs. the observed parameters ( $44 \mathrm{kDa}$ and 6.13 , respectively) gave strong reasons to reject this match. Moreover, PRUPE ppa008516mg scored very similar to the second-in- 
a

b

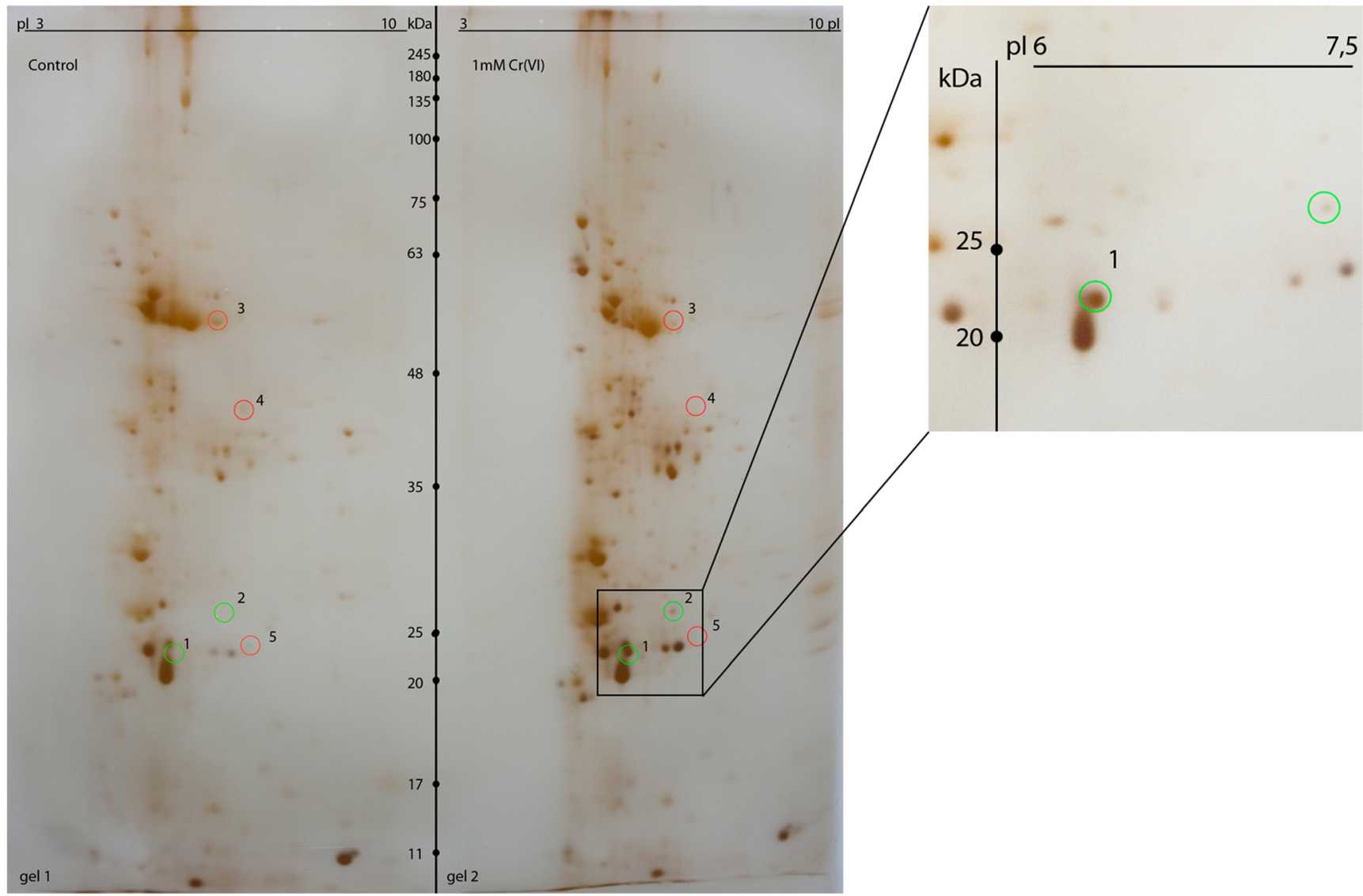

Fig. 3 2DE proteome mapping of C. cophocarpa shoots after treatment with 1-mM potassium chromate for $72 \mathrm{~h}$. a Isoelectric focusing at $\mathrm{pI}$ range $3-10$. b $2 \mathrm{DE}$ gel fragment obtained with the pI range of 5-8 to extend the marked area of the gel (a). Differentiating spots are numbered consecutively and marked with circles; spot nos. 1 and 2 represent the $\mathrm{Cr}(\mathrm{VI})$-induced proteins (green circles), nos. 3-5 indicate the downregulated proteins (red circles) order protein match of RuBisCO large chain of A. majus (Mascot scores of 369 compared to 368, respectively). In addition, the latter result was characterized by a larger number of matching peptides and higher sequence coverage (see Table 1 and Supplementary Table 1) and was further supported by several other matches with similar Mascot scores indicating $\mathrm{RuBisCO}$ from other Callitriche species (C. brutia Petagna, C. cribrosa Schotsman, C. hamulata Kütz., C. platycarpa Kütz., the results unshown). For the above reasons, the spot no. 4 was finally accepted to represent the RuBisCO large chain protein. For the spot 5, the down-regulated protein identification as a "pollen allergen" of Secale cereale L. is very difficult to interpret and suggests that it is an accidental match caused by a broad search through the huge database of Viridiplantae.

The chromate treatment proteomic data were compared with 2D protein profiles of $C$. cophocarpa shoots subjected to other stressors such as paraquat, hydrogen peroxide, sodium chloride, and elevated temperature. At this stage of the study, we focused on the gel region particularly affected by $\mathrm{Cr}(\mathrm{VI})$ presence, where the most prominent induction of proteins occurred, that is FQR1 and LHCB (the respective spots 1 and 2). The resultant fragments of protein maps are shown in Fig. 4c-f. Although they reveal some stress-specific differences when compared to the control (Fig. 4a), FQR1 and LHCB were never detected except for the Cr(VI) stress (Fig. 4b). This result proves that both proteins of interest were induced specifically by the presence of chromate.

In order to check for the QR activity of the chromateinduced FQR1 protein, extracts from Callitriche shoots preincubated with $1 \mathrm{mM} \mathrm{Cr}(\mathrm{VI})$ were tested zymographically with the menadione substrate. Figure 5 shows zymograms of native-PAGE gels obtained for the control (path $\mathrm{C}$ ) and $\mathrm{Cr}(\mathrm{VI})$-treated plants (path $\mathrm{Cr}$ ). There are two major and two minor bands visible in both paths, and they possibly reflect some unspecific menadione-reducing reactions resulting from high content of phenols (see "Discussion"). However, an additional zymographic band appeared only within the $\mathrm{Cr}$ path (indicated with an arrow), thus providing evidence of a newly produced QR activity occurring in the $\mathrm{Cr}(\mathrm{VI})$-treated plants.

The oxidative stress status of $\mathrm{Cr}(\mathrm{VI})$-treated C. cophocarpa was evaluated based on activity analyses of selected enzymes known to be responsive to such stress that is peroxidases (Px), 

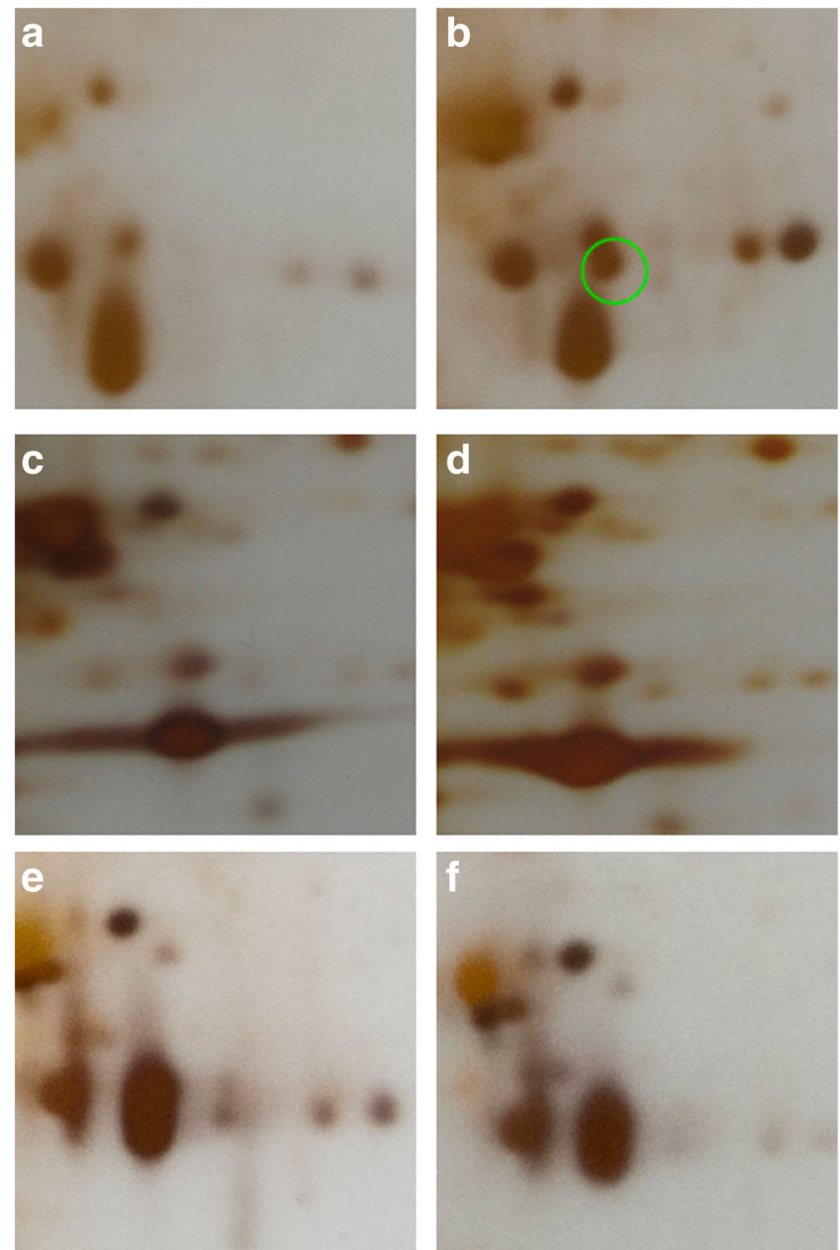

Fig. 4 2DE gel fragments revealing C. cophocarpa protein profiles within the area of chromate-induced proteins 1 and 2 (FQR1 and LHCB, respectively), obtained for different stressors: a control (no stress applied), b $\mathrm{Cr}(\mathrm{VI})$ treatment, $\mathbf{c}$ paraquat oxidative stress, d hydrogen peroxide oxidative stress, e salt stress, $\mathbf{f}$ temperature stress

CAT, and SOD. The measurements were carried out at two time intervals, which is directly after treatment $(3 \mathrm{~h})$ and after 3 -day incubation with a 1-mM chromate solution. The results were then compared to the values determined for control (untreated) plants. In Fig. 6, it can be clearly seen that $\mathrm{Cr}(\mathrm{VI})$ treatment caused over twofold induction of peroxidase(s) activity as measured after $3 \mathrm{~h}$ (from $301 \pm 38 \mathrm{U} / \mathrm{mg}$ protein to $649 \pm 45.60 \mathrm{U} / \mathrm{mg}$ ) and the elevated value was kept after 3-day incubation $(572 \pm 61.77 \mathrm{U} / \mathrm{mg})$. For CAT, in shortterm $(3 \mathrm{~h})$ incubation, a strong activity increase was observed $(0.31 \pm 0.06$ to $0.81 \pm 0.08 \mathrm{U} / \mathrm{mg})$. We note that this effect was very similar to the one caused by 15 -min stressing of Callitriche cells directly with hydrogen peroxide $(0.79 \pm$ $0.02 \mathrm{U} / \mathrm{mg}$, data not presented). However, the chromate effect on CAT activity was diminished upon long-term incubation and after 3 days, the resultant value was back at the level of control $(0.35 \pm 0.05 \mathrm{U} / \mathrm{mg})$. In the case of SOD, no statistically significant activity changes were recorded for either 3-h or 3day treatment with $\mathrm{Cr}(\mathrm{VI})$. 


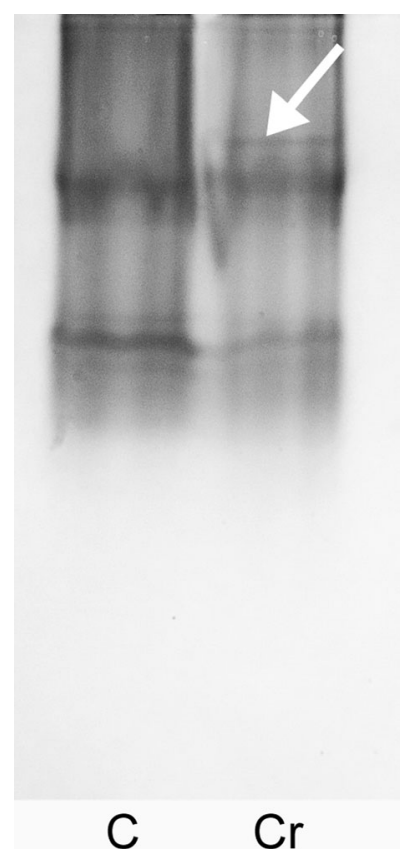

Fig. 5 Zymographic analysis of shoot protein extracts of Callitriche cophocarpa treated with 1-mM Cr(VI) for $72 \mathrm{~h}$. Enzymatic staining with a menadione substrate was done to reveal production of a novel quinone reductase activity as indicated by an arrow. C, control

\section{Discussion}

Abiotic stress is known to alter proteomic patterns in many plants (Jorrín-Novo et al. 2009). Comparative proteomics analyses can be a source of important novel information on the nature of stress tolerance and adaptation mechanisms and may suggest occurrence of newly induced biochemical pathways (Ahsan et al. 2009; Kosová et al. 2011; Timperio et al. 2008). For studies of heavy metal interactions with assimilative plant organs, aquatic plants are regarded as favorable models. Macrophytes are also preferable candidates for efficient phytoremediation in aqueous environments (Parvaiz 2016).

So far, many scientific contributions have been published, in which heavy metals were shown to affect plant proteomes (for reviews see DalCorso et al. 2013; Kosová et al. 2011; Ovečka and Takáč 2014; Visioli and Marmiroli 2013). However, the available proteomic reference data regarding chromium effect on plants is relatively poor and deal predominately with terrestrial plant models (Cvjetko et al. 2014; Hossain and Komatsu 2013; Vannini et al. 2011; Yildiz and Terzi 2016; Zemleduch-Barylska and Lorenc-Plucińska 2015). To our knowledge, there are no proteomic reports on aquatic plant-chromium interactions except that of Bah et al. (2010) which brings comparative data on $\mathrm{Cr}, \mathrm{Cd}$, and $\mathrm{Pb}$ influence on Typha angustifolia L. protein profiles. For the above reasons, the presented work is the first one to provide evidence on chromate stress-induced proteome alterations in a macrophyte with entirely submerged assimilative organs that is $C$. cophocarpa Sendtn. The expected result of this study is to find important protein changes upon chromate treatment, which we believe could explain the unusual capabilities of chromium phytoremediation by $C$. cophocarpa.

Our earlier research work revealed that $\mathrm{Cr}(\mathrm{VI})$ presence negatively affected $C$. cophocarpa shoots leading to several physiological changes such as a decrease of photosynthetic pigment content and a decline of photosynthesis quantum efficiency, distortion of leaf structure, and electrolyte leakage (Augustynowicz et al. 2010, 2013a,b). Moreover, chromate uptake was followed by its rapid reduction (Augustynowicz et al. 2013a, 2016) similarly to the other tested macrophytes Eichhornia crassipes (Mart.) Solms, Salvinia auriculata Aubl., Pistia stratiotes L., and Spirodela polyrhiza (L.) Schleid. (Espinoza-Quiñones et al. 2009; Kaszycki et al. 2005).

Unexpectedly, the results of 1D SDS-PAGE protein analyses indicated no visible alterations in the proteome of C. cophocarpa incubated with $\mathrm{Cr}(\mathrm{VI})$. Therefore, a more detailed study was undertaken employing two-dimensional electrophoresis, which enabled higher resolution of protein mapping as based on $\mathrm{pI}$ and $M_{\mathrm{W}}$ parameters. 2D electrophoreses yielded significant differences in the resultant protein profiles and showed changes in accumulation of several proteins as exemplified in Fig. 3. It should be emphasized, however, that many of the protein changes observed for a particular physiological experiment might not be linked directly to the chromate stress but rather to indigenous proteome pattern variability, which is typical of 2DE-based profiling. This variability may result from the noisiness of gene expression (Chalancon et al. 2012), intrinsic physicochemical diversity of proteins, and protein abundance differences between individual plant objects (Chandramouli and Qian 2009; Jorrín-Novo et al. 2009; Lopez 2007). The above reasons made us pick out only these spots whose densities changed in all of the gel pair replicates. Such an approach involving stringent conditions for selecting differentially abundant proteins enabled us to detect five protein alterations qualified as chromate stress specific for C. cophocarpa treated with 1-mM Cr(VI) for $72 \mathrm{~h}$ (Table 1).

In proteomic studies, the number of differentiating proteins in plants exposed to environmental stressors may vary in a broad range of several to several hundred detected spots (Kosová et al. 2011). In our recently launched experiments on 72-h chromate treatment of three other tested submerged macrophytes (S. polyrhiza, Elodea canadensis Michx., and Lemna trisulca L.), we revealed the total of 13, 12, and 21 differentially abundant proteins, respectively (Kaszycki et al., manuscript in preparation). It should be pointed out here that, besides methodological constraints of 2DE (DalCorso et al. 2013; Jorrín-Novo et al. 2009; Lopez 2007; Visioli and Marmiroli 2013), the resultant protein profile of abiotically stressed plant strongly depends on the time scale of 
Fig. 6 Specific activities of oxidative stress enzyme markers:

Px, peroxidase; CAT, catalase;

SOD, superoxide dismutase,

obtained for shoot extracts of

Callitriche cophocarpa subjected

to chromate treatment for 3 (light-

gray bars) and $72 \mathrm{~h}$ (3 days, dark-

gray bars). White bars: control

experiment (untreated shoots).

The mean values of particular

enzyme activities $(n=3 \pm \mathrm{SD})$

marked with different letters are

significantly different for $p<0.05$
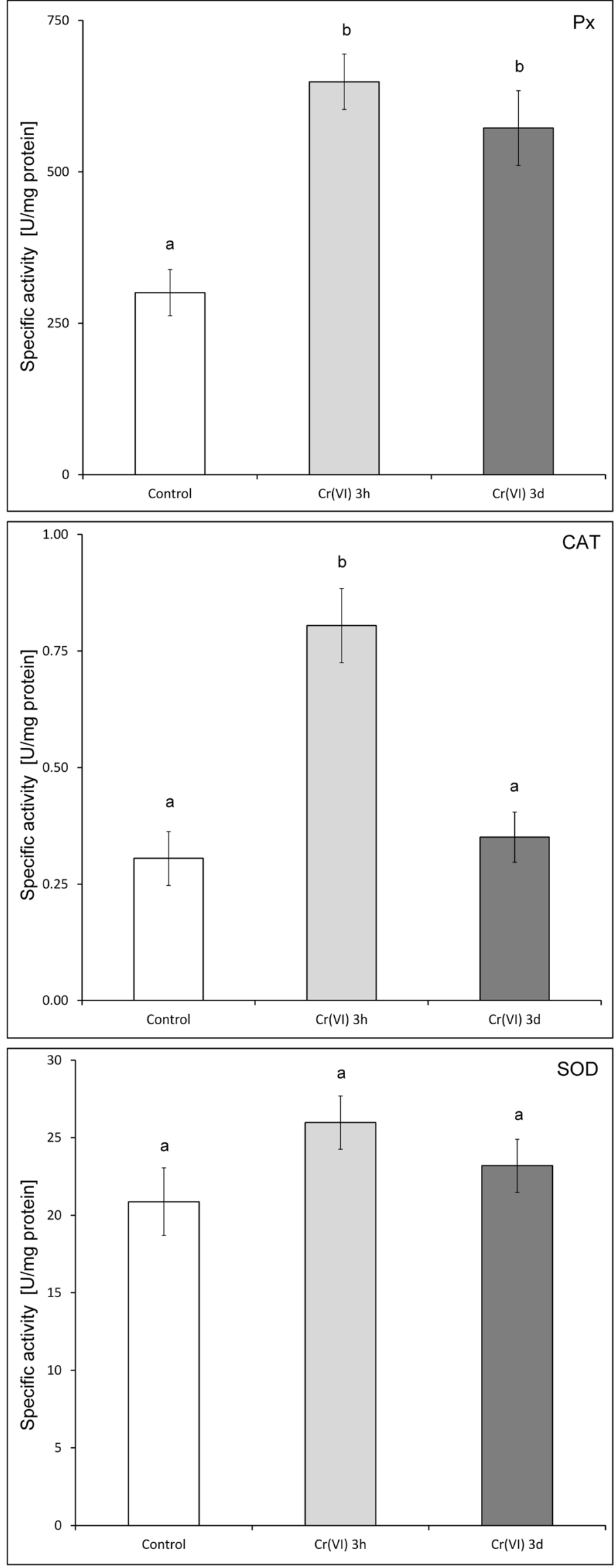
observation. Some of the early-response changes including oxidative stress reactions can be observed in a matter of hours (Kosová et al. 2011; Singh et al. 2013), whereas enhanced proteomic rearrangements are typically best pronounced within 3-5 days, which is the time required for a plant to evolve an altered phenotype due to gene induction and protein biosynthesis (Forni et al. 2012; Kosová et al. 2011; Zhao et al. 2005). In turn, in longer-term experiments, mechanisms of plant acclimation and adaptation to harsh conditions (see Bah et al. 2010 for an example) may lead to further differences in proteomic profiles.

The proteomic changes observed in this study (see Table 1) can account for several important aspects of physiologically altered phenotype of $C$. cophocarpa under chromate stress. The case of protein spot 1 (a putative FQR 1 enzyme) is discussed below in a more detail since it has possible direct consequences in terms of chromate resistance and bioremediation. The light harvesting chlorophyll $a / b$ binding protein (LHCB), identified in spot 2, was strongly induced by $\mathrm{Cr}(\mathrm{VI})$. This is an abundant membrane apoprotein of photosystem II (PSII) and is normally complexed with chlorophyll and xanthophylls to serve as the antenna complex (Jansson 1999). Importantly, the expression of the $\angle H C B$ gene was found to depend upon environmental conditions including, among others, oxidative stress (Xu et al. 2012). Therefore, the induction of this protein suggests its role in $\mathrm{Cr}$ bioremediation; however, at this stage, it is difficult to propose a particular mechanism. So far, LHCB proteins were found to be either upregulated by chromate in a $\mathrm{Cr}(\mathrm{VI})$-tolerant canola (Brassica napus L.) cultivar (Yildiz and Terzi 2016) or inhibited in a Cr(VI)-hypersensitive microphyte Pseudokirchneriella subcapitata (Korshikov) F. Hindák (Vannini et al. 2009).

$\mathrm{RuBisCO}$ (ribulose bisphosphate carboxylase), the enzyme catalyzing a key reaction of carbon dioxide fixation in photosynthesis, was down-regulated (spots 3 and 4). This was an expected result since chromate at $1-\mathrm{mM}$ concentration was shown to inhibit photosynthesis of $C$. cophocarpa (Augustynowicz et al. 2010, 2013b). RuBisCO downregulation was shown in many plant models and can be regarded as a typical response to abiotic stress including heavy metal treatments (Ahsan et al. 2009; Kosová et al. 2011). Accordingly and similarly to our observations, its accumulation decreased upon 3-day chromate incubation of both canola (Yildiz and Terzi 2016) and P. subcapitata (Vannini et al. 2009); however, under conditions of long-term (30-day) adaptation to $\mathrm{Cr}(\mathrm{VI})$, the enzyme was significantly up-regulated in Typha angustifolia (Bah et al. 2010).

Since $\mathrm{Cr}(\mathrm{VI})$ treatment is typically associated with the oxidative stress caused by elevated levels of ROS (see "Introduction"), it was of interest to verify whether C. cophocarpa triggered any relevant enzymatic radicalscavenging mechanisms and whether it could adapt during a prolonged (3-day) incubation with $\mathrm{Cr}(\mathrm{VI})$. The activities of three selected antioxidant enzymes were assayed, i.e., SOD (EC 1.15.1.1), CAT (EC 1.11.1.6), and (a sum of) peroxidases (Px). These enzymes are known as oxidative stress markers in plants (Geebelen et al. 2002) and were reported earlier to be responsive to chromate (Shanker et al. 2005). SOD acts as a scavenger of the superoxide anion, whereas CAT and Pxs catalytically eliminate hydrogen peroxide. At first, a 3-h treatment was examined, which revealed direct reaction to $\mathrm{Cr}(\mathrm{VI})$ by strongly increasing CAT and peroxidase activities. This earlyresponse stage (an alarm phase of plant response as indicated by Kosová et al. 2011) is consistent with our previous observations which showed immediate reaction of $C$. cophocarpa shoots treated with chromate and manifested by a rapid (in a matter of hours) reduction of $\mathrm{Cr}(\mathrm{VI})$ to the $\mathrm{Cr}(\mathrm{V})$ intermediate which is generated upon $\mathrm{Cr}(\mathrm{VI}) \rightarrow \mathrm{Cr}(\mathrm{III})$ bioconversion (Augustynowicz et al. 2013a, 2016). During prolonged (3day) incubation, only Px activities were kept elevated while CAT was back at the level determined for control plants.

SOD, CAT, and peroxidase induction and/or activation are known to play a major role in heavy metal detoxication in plants (Ahsan et al. 2009). However, in plants treated with chromate, as reviewed by Shanker et al. (2005) and Singh et al. (2013), the activity of these enzymes increased only at relatively low chromate concentrations (usually of the order of micromoles per liter) whereas the excess of $\mathrm{Cr}(\mathrm{VI})$ (most typically above $100 \mu \mathrm{M}$ ) led to significant activity inhibition. The fact that in C. cophocarpa the activity of both SOD and CAT remained at control levels under harsh conditions of 3-day 1$\mathrm{mM} \mathrm{Cr}(\mathrm{VI})$ presence, it brings additional evidence that the studied macrophyte could induce enhanced resistance to oxidative stress. In the context of the above, the mechanism of long-term activation of peroxidases under chromate treatment needs further research. These enzymes were previously shown to be efficient scavengers of heavy metal borne $\mathrm{H}_{2} \mathrm{O}_{2}$ (Ahsan et al. 2009). However, the increase of Px activities as observed in enzymatic assays was not reflected in 2DE analyses by elevated abundance of any known peroxidase. This result can be explained by the stimulation of enzymatic activity with biochemical regulatory mechanisms rather than by induced expression. Similar discrepancies were reported by other authors who detected peroxidase activity stimulation by $\mathrm{Cr}$ (Zemleduch-Barylska and Lorenc-Plucińska 2015) or Cd (e.g., Yang et al. 2015; Kieffer et al. 2009) but observed no accumulation changes in 2DE profiling.

Taken the above findings together, it appears that C. cophocarpa shoots can adapt to $1-\mathrm{mM} \mathrm{Cr}(\mathrm{VI})$ within 3 days by increasing activity of peroxidases while maintaining the levels of the other antioxidant enzymes: SOD and CAT. This, in turn, indicates the tendency to suppress oxidative stress and suggests that chromate presence can launch protective mechanisms resulting in lowered pool of toxic ROS.

The FQR1 protein as identified in spot 1 of the electrophoretic gel (the highest score of $V$. vinifera $\mathrm{NAD}(\mathrm{P}) \mathrm{H}$ quinone 
dehydrogenase, see Fig. 3 and Table 1) was shown to be very strongly and specifically induced by chromate. Its presence was always well pronounced only in $\mathrm{Cr}$-treated plants whereas both under control conditions and in all cases of other stressors (Fig. 4a, c-f), the electrophoretic gels lacked accumulation of any protein related to FQR1. A closer look at this enzyme enables us to suggest its direct involvement in chromate bioremediation as a putative quinone and/or chromate reductase. Extensive database search (www.ebi.ac.uk/interpro/protein/ Q9LSQ5, accession date: July 2017) following the NCBI protein identification accessions gave more information on the enzyme identity. The FQR1 domain is not unique and can be found in several flavoproteins. It belongs to a big family of highly conserved flavin-binding reductases occurring in plants, fungi, archaea, and eubacteria and shares some homologies with mammalian quinone reductases (Laskowski et al. 2002). In particular, a NAD(P)H:quinone oxidoreductase can reduce quinones to the hydroquinone state in a twoelectron reaction, which prevents the interaction of the semiquinone with $\mathrm{O}_{2}$ and thus disables production of toxic superoxide. So, the enzyme has been postulated to function as a protective agent in oxidative stress response and to participate in detoxifying reactions (Berczi and Moller 2000; Laskowski et al. 2002).

Zymographic analyses (see the enzymatic band indicated by an arrow in Fig. 5) made it possible to prove that the QR activity was indeed induced in Callitriche treated with chromate. To detect an in vitro QR activity in $\mathrm{Cr}(\mathrm{VI})$-stressed plants, we used a modified assay enabling to visualize the enzyme in native-PAGE gels. Such an approach was necessary since the standard laboratory assays (data unshown) failed to bring conclusive results, yielding high apparent (background) activities, possibly due to high abundance of phenolics in C. cophocarpa (Augustynowicz et al. 2014a).

It should be emphasized here that $\mathrm{QR}$ activities in $\mathrm{Cr}(\mathrm{VI})$ stressed plants have not been reported to date. Although quinone oxidoreductases are ubiquitous among plant species, there are only a few proteomic studies providing evidence of QRs being responsive to other heavy metals or metalloids. First, Requejo and Tena (2005) showed a p-benzoquinone reductase (bQR) induction in a maize (Zea mays L.) root proteome treated with arsenic and proposed a protective role of the enzyme against oxidative stress. For cadmium-stressed plants, Kieffer et al. (2009) reported strong up-regulation of FQR1 as well as several other bQR-like and putative QR proteins in poplar leaves. Zhao et al. (2011), in turn, revealed enhanced accumulation of $\mathrm{bQR}$ in a leaf proteome of a Cd-hyperaccumulator Phytolacca americana L. Recently, Chen et al. (2015) detected a protein described as a "putative quinone reductase 2 " in the proteome of $\mathrm{Cu}$-stressed rice (Oryza sativa L.).

There is scientific evidence enabling us to hypothesize that the induction of the newly identified FQR1 enzyme plays an important role in the mechanism of chromate bioreduction as observed in Callitriche. $\mathrm{Cr}$ (VI) biological reduction process has been documented for plants as well as for all other organisms: pro- and eukaryotic microbes, fungi, algae, and animals (Joutey et al. 2015; Singh et al. 2013; Zhitkovich 2011). In general, hexavalent chromate reduction may involve both extra- and intracellular processes and both enzymatic and non-enzymatic mechanisms. For $\mathrm{Cr}(\mathrm{VI})$ bioconversion inside cell, the reduction process may have two contradictory aspects: first, it can result in cellular toxicity due to oxidative stress, and second, it can serve as a bioremediation (resistance) mechanism. In the first case, single-electron reactions lead to generation of detrimental ROS (Cheung and Gu, 2007; Zhitkovich 2011; Thatoi et al. 2014) which in turn induce antioxidative metabolism producing cellular antioxidants (Panda and Choudhury 2005; Singh et al. 2013). In the second case, the cellular $\mathrm{Cr}(\mathrm{VI}) \rightarrow \mathrm{Cr}(\mathrm{III})$ conversion is achieved preferably via a two-electron transfer systems which enable an organism to cope with the chromate stress by safely (that is minimizing ROS production) reducing the original hexavalent form to the less mobile and thus less reactive $\mathrm{Cr}$ (III) (RamírezDíaz et al. 2008; Joutey et al. 2015).

Several enzymes capable of $\mathrm{Cr}(\mathrm{VI})$ reduction have been described, first identified in bacteria where various chromate reductases were shown to influence microbial resistance to Cr(VI) (Ramírez-Díaz et al. 2008; Thatoi et al. 2014 and the references therein). Note that these reported chromatereducing activities relied upon either one- or two-electron mechanisms, which resulted in different strain sensitivities to chromate as discussed above. Importantly, the two-electron $\mathrm{Cr}(\mathrm{VI})$ reduction systems that enable safer $\mathrm{Cr}(\mathrm{VI})$ detoxication were typically linked to soluble flavin mononucleotidebinding oxidoreductases producing QR activities. These enzymes were induced by chromate and identified as bacterial chromate reductases because they could use $\mathrm{Cr}(\mathrm{VI})$ as a possible terminal electron acceptor (Eswaramoorthy et al. 2012; Thatoi et al. 2014).

Besides bacteria, $\mathrm{Cr}(\mathrm{VI})$-reducing activities were also observed in yeast, microalgae, fungi (Joutey et al. 2015; Viti et al. 2014), as well as plants (Prado et al. 2016; Shanker et al. 2009) including macrophytes (Espinoza-Quiñones et al. 2009; Kaszycki et al. 2005) and C. cophocarpa in particular (Augustynowicz et al. 2013a, 2016). Importantly, for the latter case, chromate bioreduction occurred exclusively within the plant shoots and was not observed outside the macrophyte tissue (that is in a surrounding growth medium). This result was based on a low-frequency in vivo electron paramagnetic resonance study (Augustynowicz et al. 2013a) which revealed that $C$. cophocarpa chromate phytoremediation involved $\mathrm{Cr}(\mathrm{VI})$ intratissular reductive conversion generating a $\mathrm{Cr}(\mathrm{V})$ intermediate.

As regards plants, chromate reductases have not been identified in vivo, yet. However, in a study on Arabidopsis thaliana (L.) Heynh., Sparla et al. (2003) documented that a 
flavoenyzme NAD(P)H:quinone oxidoreductase (NQR) shared sequence homologies with some bacterial chromate reductases. This led the authors to the idea that the enzyme could function as a chromate reductase and thus promote $\mathrm{Cr}$ phytoremediation. Using A. thaliana homogenates, they detected a NQR-based NADPH-chromate reductase activity in in vitro tests. Note however, that the Arabidopsis NQR protein, unlike the enzyme identified in this study, was not inducible and it belonged to a different family of quinone reductases, poorly related to the FQR domains (Heyno et al. 2013). Later, Shanker et al. (2009), based on extensive bioinformatic database search, speculated that putative plant chromate reductases homologous to the microbial ones might take part in $\mathrm{Cr}(\mathrm{VI})$ detoxification.

Taking all the above facts into consideration it is tempting to suggest that $C$. cophocarpa $\mathrm{FQR} 1$ quinone reductase shows chromate-reducing activity and is an important factor involved in $\mathrm{Cr}(\mathrm{VI})$ bioremediation. However, the postulated role of the enzyme still awaits direct experimental evidence. If the novel enzyme proved to reduce $\mathrm{Cr}(\mathrm{VI})$ substrate both in vitro and in vivo, its induction with chromate would indicate that C. cophocarpa is the first known aquatic plant to have developed some specific enzymatic detoxifying mechanism against $\mathrm{Cr}(\mathrm{VI})$ action. This, in turn, would imply that our plant model could combine high Cr-resistance with enhanced metal accumulation and biomass yield thus making C. cophocarpa even better choice for efficient phytoremediation of polluted waters.

\section{Concluding remarks}

Proteomic pattern alterations observed for C. cophocarpa treated with sublethal chromate levels are not extensive and involve only several proteins revealing changed accumulation. Among the differentially abundant proteins, the induction of a flavoenzyme FQR1-like quinone reductase (QR) is the most significant finding. This enzyme is expected to be a detoxification factor that protects the cells against the $\mathrm{Cr}(\mathrm{VI})$ generated oxidative stress via catalyzing transfer of two electrons from $\mathrm{NAD}(\mathrm{P}) \mathrm{H}$ to hexavalent chromium. QR expression is chromate-specific since it is not induced by any other stressful conditions (salt, temperature, and oxidative stress) and in C. cophocarpa, it might function as a part of the evolved enzymatic $\mathrm{Cr}(\mathrm{VI})$ reduction pathway, analogous to that described for aerobically grown Gram-negative rods.

This is the first study to show specific plant response to chromate stress by inducing an antioxidant enzyme with potential chromate reductase activity. For the case of C. cophocarpa and possibly other macrophytes capable of efficient $\mathrm{Cr}$ phytoremediation, the existence of such a mechanism would contribute to their chromium-resistance phenotype and thus enhance environmental applicability.
Acknowledgements We greatly appreciate helpful discussions with Prof. Cinzia Forni (Università di Roma "Tor Vergata", Italy) regarding stress reactions of aquatic plants and with Agata Malinowska, M.Sc. (Laboratory of Mass Spectrometry, Institute of Biochemistry and Biophysics, Polish Academy of Sciences), regarding Mascot data interpretation. We are also indebted to Dr. Magdalena Kwolek-Mirek (University of Rzeszów, Poland) and Dr. Anna Kołton (University of Agriculture, Kraków, Poland) for their advice on oxidative stress induction and monitoring in C. cophocarpa.

Funding information The work was financially supported by the research grant of the Polish National Science Centre No. DEC-2011/03/B/NZ9/ 00952. The equipment used for MS-based protein identification was in part sponsored by the Centre for Preclinical Research and Technology (CePT), a project supported by the European Regional Development Fund and Innovative Economy, the National Cohesion Strategy of Poland (http://www.ibb.waw.pl/en/services/mass-spectrometry-lab).

Open Access This article is distributed under the terms of the Creative Commons Attribution 4.0 International License (http:// creativecommons.org/licenses/by/4.0/), which permits unrestricted use, distribution, and reproduction in any medium, provided you give appropriate credit to the original author(s) and the source, provide a link to the Creative Commons license, and indicate if changes were made.

\section{References}

Aebi H (1984) Catalase in vitro. Methods Enzymol 105:121-126. https:// doi.org/10.1016/S0076-6879(84)05016-3

Ahsan N, Renaut J, Komatsu S (2009) Recent developments in the application of proteomics to the analysis of plant responses to heavy metals. Proteomics 9(10):2602-2621. https://doi.org/10.1002/pmic. 200800935

Augustynowicz J, Grosicki M, Hanus-Fajerska E, Lekka M, Waloszek A, Kołoczek H (2010) Chromium(VI) bioremediation by aquatic macrophyte Callitriche cophocarpa Sendtn. Chemosphere 79(11):1077-1083. https://doi.org/10.1016/j. chemosphere.2010.03.019

Augustynowicz J, Kołton AM, Baran AM et al (2013a) Strategy of Cr detoxification by Callitriche cophocarpa. Cent Eur J Chem 11(2): 295-303. https://doi.org/10.2478/s11532-012-0161-8

Augustynowicz J, Kyzioł-Komosińska J, Smoleń S, Waloszek A (2013b) Study on chromium-binding capacity of Callitriche cophocarpa in an aquatic environment. Arch Environ Contam Toxicol 64(3):410 418. https://doi.org/10.1007/s00244-012-9853-5

Augustynowicz J, Długosz-Grochowska OG, Kostecka-Gugała AM, Leja M, Kruczek MK, Świderski A (2014a) Callitriche cophocarpa - a new rich source of active phenolic compounds. Cent Eur J Chem 12(4):519-527. https://doi.org/10.2478/s11532013-0404-3

Augustynowicz J, Tokarz K, Baran A, Płachno BJ (2014b) Phytoremediation of water polluted by thallium, cadmium, zinc and lead with the use of macrophyte Callitriche cophocarpa. Arch Env Contam Toxicol 66(4):572-581. https://doi.org/10.1007/ s00244-013-9995-0

Augustynowicz J, Gajewski Z, Kostecka-Gugała A, Wróbel P, Kołton A (2016) Accumulation patterns of $\mathrm{Cr}$ in Callitriche organs - qualitative and quantitative analysis. Environ Sci Pollut Res 23(3):2669 2676. https://doi.org/10.1007/s11356-015-5499-y

Bah AM, Sun H, Chen F, Zhou J, Dai H, Zhang G, Wu F (2010) Comparative proteomic analysis of Typha angustifolia leaf under chromium, cadmium and lead stress. J Hazard Mater 184(1-3): 191-203. https://doi.org/10.1016/j.jhazmat.2010.08.023 
Beauchamp C, Fridovich I (1971) Superoxide dismutase: improved assays and an assay applicable to acrylamide gels. Anal Biochem 44(1):276-287. https://doi.org/10.1016/0003-2697(71)90370-8

Berczi A, Moller IM (2000) Redox enzymes in the plant plasma membrane and their possible roles. Plant Cell Environ 23(12):12871302. https://doi.org/10.1046/j.1365-3040.2000.00644.x

Bradford MM (1976) A rapid and sensitive method for the quantitation of microgram quantities of protein utilizing the principle of protein-dye binding. Anal Biochem 72(1-2):248-254. https://doi.org/10.1016/ 0003-2697(76)90527-3

Cervantes C, Campos-García J, Devars S, Gutiérrez-Corona F, LozaTavera H, Torres-Guzmán JC, Moreno-Sánchez R (2001) Interactions of chromium with microorganisms and plants. FEMS Microbiol Rev 25(3):335-347. https://doi.org/10.1016/S01686445(01)00057-2

Chalancon G, Ravarani C, Balaji S et al (2012) Interplay between gene expression noise and regulatory network architecture. Trends Genet 28(5):221-232. https://doi.org/10.1016/j.tig.2012.01.006

Chandra P, Kulshreshtha K (2004) Chromium accumulation and toxicity in aquatic vascular plants. Bot Rev 70(3):313-327

Chandramouli K, Qian PY (2009) Proteomics: challenges, techniques and possibilities to overcome biological sample complexity. Hum Genomics Proteomics 2009:1-22. https://doi.org/10.4061/2009/ 239204

Chatterjee M, Gupta S, Bhar A, Das S (2012) Optimization of an efficient protein extraction protocol compatible with two-dimensional electrophoresis and mass spectrometry from recalcitrant phenolic rich roots of chickpea (Cicer arietinum L.) Int J Proteomics 2012:1-10. https://doi.org/10.1155/2012/536963

Chen C, Song Y, Zhuang K, Li L, Xia Y, Shen Z (2015) Proteomic analysis of copper-binding proteins in excess copper-stressed roots of two rice (Oryza sativa L.) varieties with different $\mathrm{Cu}$ tolerances. PLoS One 10(4):e0125367. https://doi.org/10.1371/journal.pone. 0125367

Cheung KH, Gu JD (2007) Mechanism of hexavalent chromium detoxification by microorganisms and bioremediation application potential: a review. Int Biodeterior Biodegrad 59(1):8-15. https://doi.org/ 10.1016/j.ibiod.2006.05.002

Cvjetko P, Zovko M, Balen B (2014) Proteomics of heavy metal toxicity in plants. Arh Hig Rada Toxikol 65(1):1-18. https://doi.org/10. 2478/10004-1254-65-2014-2443

DalCorso G, Fasani E, Furini A (2013) Recent advances in the analysis of metal hyperaccumulation and hypertolerance in plants using proteomics. Front Plant Sci 4:280: 1-7. https://doi.org/10.3389/fpls.2013. 00280

Dalvi AA, Bhalerao SA (2013) Response of plants towards heavy metal toxicity: an overview of avoidance, tolerance and uptake mechanism. Ann Plant Sci 2:362-368

Shanker AK, Djanaguiraman M, Venkateswarlu B (2009) Chromium interactions in plants: current status and future strategies. Metallomics 1(5):375-383. https://doi.org/10.1039/b904571f

Espinoza-Quiñones FR, Martin N, Stutz G, Tirao G, Palácio SM, Rizzutto MA, Módenes AN, Silva FG Jr, Szymanski N, Kroumov AD (2009) Root uptake and reduction of hexavalent chromium by aquatic macrophytes as assessed by high-resolution X-ray emission. Water Res 43(17):4159-4166. https://doi.org/10.1016/j.watres. 2009.06.041

Eswaramoorthy S, Poulain S, Hienerwadel R, Bremond N, Sylvester MD, Zhang YB, Berthomieu C, van der Lelie D, Matin A (2012) Crytsal structure of $\mathrm{ChrR}$ - a quinone reductase with the capacity to reduce chromate. PLoS One 7(4):e36017. https://doi.org/10.1371/journal. pone. 0036017

Favas PJC, Pratas J, Prasad MNV (2012) Accumulation of arsenic by aquatic plants in large-scale field conditions: opportunities for phytoremediation and bioindication. Sci Total Environ 433:390 397. https://doi.org/10.1016/j.scitotenv.2012.06.091
Favas PJC, Pratas J, Varunc M et al (2014) Accumulation of uranium by aquatic plants in field conditions: prospects for phytoremediation. Sci Total Environ 470-471:993-1002. https://doi.org/10.1016/j. scitotenv.2013.10.067

Forni C, Braglia R, Harren FJM, Cristescu SM (2012) Stress responses of duckweed (Lemna minor L.) and water velvet (Azolla filiculoides Lam.) to anionic surfactant sodium-dodecyl-sulphate (SDS). Aquat Toxicol 110-111:107-113. https://doi.org/10.1016/j.aquatox.2011. 12.017

Geebelen W, Vangronsveld J, Adriano DC, van Poucke LC, Clijsters H (2002) Effects of Pb-EDTA and EDTA on oxidative stress reactions and mineral uptake in Phaseolus vulgaris. Physiol Plant 115(3): 377-384. https://doi.org/10.1034/j.1399-3054.2002.1150307.x

Heyno E, Alkan N, Fluhr R (2013) A dual role for plant quinone reductases in host-fungus interaction. Physiol Plant 149:340-353. https:// doi.org/10.1111/ppl.12042

Hossain Z, Komatsu S (2013) Contribution of proteomic studies towards understanding plant heavy metal stress response. Front Plant Sci 3: 310. https://doi.org/10.3389/fpls.2012.00310

Jansson S (1999) A guide to the $L h c$ genes and their relatives in Arabidopsis. Trends Plant Sci 4(6):236-240. https://doi.org/10. 1016/S1360-1385(99)01419-3

Jorrín-Novo J, Maldonado AM, Echevarría-Zomeño S et al (2009) Plant proteomics update (2007-2008): second-generation proteomic techniques, an appropriate experimental design, and data analysis to fulfill MIAPE standards, increase plant proteome coverage and expand biological knowledge. J Proteome 72(3):285-314. https://doi. org/10.1016/j.jprot.2009.01.026285

Joutey NT, Sayel H, Bahafid W, Ghachtouli NE (2015) Mechanisms of hexavalent chromium resistance and removal by microorganisms. In: Whitacre DM (ed) Reviews of Environmental Contamination and Toxicology, vol 233. Springer International Publishing, Switzerland, pp 45-69. https://doi.org/10.1007/978-3-319-10479-9 2

Jungblut PR, Seifert R (1990) Analysis by high-resolution two-dimensional electrophoresis of differentiation-dependent alterations in cytosolic protein pattern of HL-60 leukemic cells. J Biochem Biophys Methods 21(1):47-58. https://doi.org/10.1016/0165-022X(90) 90044-D

Kaszycki P, Gabryś H, Appenroth KJ et al (2005) Exogenously applied sulphate as a tool to investigate transport and reduction of chromate in the duckweed Spirodela polyrhiza. Plant Cell Environ 28(2):260 268. https://doi.org/10.1111/j.1365-3040.2004.01276.x

Kieffer P, Schröder P, Dommes J, Hoffmann L, Renaut J, Hausman JF (2009) Proteomic and enzymatic response of poplar to cadmium stress. J Proteome 72(3):379-396. https://doi.org/10.1016/j.jprot. 2009.01.014

Kosová K, Vítámvás P, Prášil IT, Renaut J (2011) Plant proteome changes under abiotic stress - contribution of proteomics studies to understanding plant stress response. J Proteome 74(8):1301-1322. https:// doi.org/10.1016/j.jprot.2011.02.006

Kotaś J, Stasicka Z (2000) Chromium occurrence in the environment and methods of its speciation. Environ Pollut 107(3):263-283. https:// doi.org/10.1016/S0269-7491(99)00168-2

Laemmli UK (1970) Cleavage of structural proteins during the assembly of the head of bacteriophage T4. Nature 227(5259):680-685. https:// doi.org/10.1038/227680a0

Laskowski MJ, Dreher KA, Gehring MA, Abel S, Gensler AL, Sussex IM (2002) FQR1, a novel primary auxin-response gene, encodes a flavin mononucleotide-binding quinone reductase. Plant Physiol 128(2):578-590. https://doi.org/10.1104/pp.010581.Abel

Lopez JL (2007) Two-dimensional electrophoresis in proteome expression analysis. J Chromatogr B 849(1-2):190-202. https://doi.org/10. 1016/j.jchromb.2006.11.049

Lück H (1963) Peroxidase. In: Bergmeyer HU (ed) Methods of Enzymatic Analysis. Academic Press, New York, pp 895-897 
Murashige T, Skoog F (1962) A revised medium for rapid growth and bioassays with tobacco tissue cultures. Physiol Plant 15(3):473-497. https://doi.org/10.1111/j.1399-3054.1962.tb08052.x

Oliveira H (2012) Chromium as an environmental pollutant: insights on induced plant toxicity. J Bot 2012, 8 p:375843. https://doi.org/10. $1155 / 2012 / 375843$

Ovečka M, Takáč T (2014) Managing heavy metal toxicity stress in plants: biological and biotechnological tools. Biotechnol Adv 32(1):73-86. https://doi.org/10.1016/j.biotechadv.2013.11.011

Panda SK, Choudhury S (2005) Chromium stress in plants. Braz J Plant Physiol 17(1):95-102. https://doi.org/10.1590/S167704202005000100008

Parvaiz A (2016) Plant metal interaction: emerging remediation techniques. Elsevier Inc, Amsterdam. https://doi.org/10.1016/B978-012-803158-2.00006-0

Prado FE, Hila M, Chocobar-Ponce S et al (2016) Chromium and the plant: a dangerous affair? In: Parvaiz A (ed) Plant metal interaction: emerging remediation techniques. Elsevier Inc, Amsterdam, pp 149-177. https://doi.org/10.1016/B978-0-12-803158-2.00006-0

Prochaska HJ, Santamaria AB (1988) Direct measurement of NAD(P)H: quinone reductase from cells cultured in microtiter wells: a screening assay for anticarcinogenic enzyme inducers. Anal Biochem 169(2):328-336. https://doi.org/10.1016/0003-2697(88)90292-8

Ramírez-Díaz MI, Díaz-Pérez C, Vargas E, Riveros-Rosas H, CamposGarcía J, Cervantes C (2008) Mechanisms of bacterial resistance to chromium compounds. Biometals 21(3):321-332. https://doi.org/ 10.1007/s10534-007-9121-8

Requejo R, Tena M (2005) Proteome analysis of maize roots reveals that oxidative stress is a main contributing factor to plant arsenic toxicity. Phytochemistry 66(2005):1519-1528. https://doi.org/10.1016/j. phytochem.2005.05.003

Saha R, Nandi R, Saha B (2011) Sources and toxicity of hexavalent chromium. Rev J Coord Chem 64(10):1782-1806. https://doi.org/ $10.1080 / 00958972.2011 .583646$

Shadreck M, Mugadza T (2013) Chromium, an essential nutrient and pollutant: a review. Afr J Pure Appl Chem 7:310-317. https://doi. org/10.5897/AJPAC2013.0517

Shanker AK, Cervantes C, Loza-Tavera H, Avudainayagam S (2005) Chromium toxicity in plants. Environ Int 31(5):739-753. https:// doi.org/10.1016/j.envint.2005.02.003

Sharma S, Pennington LP, Steele VE (1996) Induction of NADPHquinone reductase as a screening assay for potential chemopreventive agents. Methods Cell Sci 19(1):63-66. https://doi.org/10.1023/ A:1009706923716

Singh HP, Mahajan P, Kaur S, Batish DR, Kohli RK (2013) Chromium toxicity and tolerance in plants. Environ Chem Lett 11(3):229-254. https://doi.org/10.1007/s10311-013-0407-5

Sparla F, Peciccia M, Pupillo P, Trost P (2003) Arabidopsis thaliana NQR (NAD(P)H:quinone oxidoreductase) reduces hexavalent chromium. In: Proceedings of Societa' Italiana Di Biologia Vegetale Congress. Abstract available at: http://www.sibv.it/congressi/2003

Zhao L, Sun Y-L, Cui S-X, Chen M, Yang HM, Liu HM, Chai TY, Huang F (2011) Cd-induced changes in leaf proteome of the hyperaccumulator plant Phytolacca americana. Chemosphere 85(2011):56-66. https://doi.org/10.1016/j.chemosphere.2011.06. 029
Tel-Or E, Forni C (2011) Phytoremediation of hazardous toxic metals and organics by photosynthetic aquatic systems. Plant Biosystems 145(1):224-235. https://doi.org/10.1080/11263504.2010.509944

Thatoi H, Das S, Mishra J et al (2014) Bacterial chromate reductase, a potential enzyme for bioremediation of hexavalent chromium: a review. J Environ Manag 146:383-e399. https://doi.org/10.1016/j. jenvman.2014.07.014

Timperio AM, Egidi MG, Zolla L (2008) Proteomics applied on plant abiotic stresses: role of heat shock proteins (HSP). J Proteome 71(4): 391-411. https://doi.org/10.1016/j.jprot.2008.07.005

Vannini C, Marsoni M, Domingo G, Antognoni F, Biondi S, Bracale M (2009) Proteomic analysis of chromate-induced modifications in Pseudokirchneriella subcapitata. Chemosphere 76(2009):13721379. https://doi.org/10.1016/j.chemosphere.2009.06.022

Vannini C, Domingo G, Marsoni M, Bracale M, Sestili S, Ficcadenti N, Speranza A, Crinelli R, Carloni E, Scoccianti V (2011) Proteomic changes and molecular effects associated with $\mathrm{Cr}(\mathrm{III})$ and $\mathrm{Cr}(\mathrm{VI})$ treatments on germinating kiwifruit pollen. Phytochemistry 72(1415):1786-1795. https://doi.org/10.1016/j.phytochem.2011.06.001

Visioli G, Marmiroli N (2013) The proteomics of heavy metal hyperaccumulation by plants. J Proteome 79:133-145. https://doi. org/10.1016/j.jprot.2012.12.006

Viti C, Marchi E, Decorosi F, Giovannetti L (2014) Molecular mechanisms of $\mathrm{Cr}(\mathrm{VI})$ resistance in bacteria and fungi. FEMS Microbiol Rev 38(4):633-659. https://doi.org/10.1111/1574-6976.12051

$\mathrm{Xu}$ YH, Liu R, Yan L et al (2012) Light-harvesting chlorophyll $a / b$ binding proteins are required for stomatal response to abscisic acid in Arabidopsis. J Exp Bot 63(3):1095-1106. https://doi.org/10. 1093/jxb/err315

Yang X, Feng Y, He ZL, Stoffella PJ (2005) Molecular mechanisms of heavy metal hyperaccumulation and phytoremediation. J Trace Elem Med Biol 18(4):339-353. https://doi.org/10.1016/j.jtemb. 2005.02.007

Yang Y, Li X, Yang S, Zhou Y, Dong C, Ren J, Sun X, Yang Y (2015) Comparative physiological and proteomic analysis reveals the leaf response to cadmium-induced stress in poplar (Populus yunnanensis). PLoS One 10(9):e0137396. https://doi.org/10.1371/ journal.pone. 0137396

Yildiz M, Terzi H (2016) Proteomic analysis of chromium stress and sulfur deficiency responses in leaves of two canola (Brassica napus L.) cultivars differing in $\mathrm{Cr}(\mathrm{VI})$ tolerance. Ecotoxicol Environ Saf 124:255-266. https://doi.org/10.1016/j.ecoenv.2015.10.023

Zayed AM, Terry N (2003) Chromium in the environment: factors affecting biological remediation. Plant Soil 249(1):139-156. https://doi. org/10.1023/A:1022504826342

Zemleduch-Barylska A, Lorenc-Plucińska G (2015) Populus $\times$ canescens grown on Cr-rich tannery waste: comparison of leaf and root biochemical and proteomic responses. Plant Physiol Biochem PPB / Société Fr Physiol végétale 90:1-13. https://doi.org/10.1016/j. plaphy.2015.02.014

Zhao J, Davis LC, Verpoorte R (2005) Elicitor signal transduction leading to production of plant secondary metabolites. Biotechnol Adv 23(4): 283-333. https://doi.org/10.1016/j.biotechadv.2005.01.003

Zhitkovich A (2011) Chromium in drinking water: sources, metabolism, and cancer risks. Chem Res Toxicol 24(10):1617-1629. https://doi. org/10.1021/tx200251t 